\title{
Avocado: characteristics, health benefits and uses
}

\author{
Abacate: características, benefícios à saúde e aplicações
}

\section{Patrícia Fonseca Duarte $^{\mathrm{I}}$ Marcia Alves Chaves ${ }^{\mathrm{II}}$ Caroline Dellinghausen Borges ${ }^{\text {III }}$ Carla Rosane Barboza Mendonça ${ }^{\text {II" }}$}

\section{ABSTRACT}

This study aimed to present a literature review about the characteristics, applications, and potential of avocado (Persea americana). Avocado is considered one of the main tropical fruits, as it contains fat-soluble vitamins which are less common in other fruits, besides high levels of protein, potassium and unsaturated fatty acids. Avocado pulp contains variable oil content, and is widely used in the pharmaceutical and cosmetics industry, and in the production of commercial oils similar to olive oil. This fruit has been recognized for its health benefits, especially due to the compounds present in the lipidic fraction, such as omega fatty acids, phytosterols, tocopherols and squalene. Studies have shown the benefits of avocado associated to a balanced diet, especially in reducing cholesterol and preventing cardiovascular diseases. The processed avocado pulp is an alternative to utilize fruits, which can be used in various value-added food products. Fluid extract of the avocado leaves is widely used in pharmaceutical products, mainly due to the diuretic characteristic of the present compounds in plant leaves. With the increasing research supporting the nutritional characteristics and benefits of avocado, the tendency is to increase the production and exploitation of this raw material in Brazil, as also observed in other countries.

Key words: avocado tree, avocado oil, unsaturated fatty acid, bioactive compounds.

\section{RESUMO}

Objetivou-secomestetrabalhoapresentarumarevisão da literatura sobre as características, aplicações e potencialidades do abacate (Persea americana). O abacate é considerado um dos principais frutos tropicais, pois possui as vitaminas lipossolúveis que, em geral, são deficientes nas outras frutas. Além destas, contém proteinas e elevados teores de potássio e ácidos graxos insaturados. Apresenta quantidade variável de óleo na polpa, sendo esta vastamente utilizada nas indústrias farmacêtica e de cosméticos, e na obtenção de óleos comerciais similares ao azeite de oliva. Esse fruto tem sido reconhecido por seus beneficios à saúde, especialmente em função dos compostos presentes na fração lipídica, como ácidos graxos ômega, fitoesterois, tocoferois e esqualeno. Estudos têm demonstrado os beneficios do abacate associado a uma dieta balanceada, principalmente, na redução do colesterol e na prevenção de doenças cardiovasculares. A polpa do abacate na forma processada é uma alternativa para aproveitar os frutos, passivel de ser utilizada em diversos produtos alimentícios de maior valor agregado. O extrato fluido das folhas do abacateiro é muito utilizado em produtos farmacêuticos, principalmente, pelo caráter diurético de compostos presentes nas folhas da planta. Com o aumento das pesquisas que comprovam as características nutricionais e os beneficios do abacate, a tendência é aumentar a produção e exploração dessa matéria-prima no Brasil, como já acontece em outros países.

Palavras-chave: abacateiro, óleo de abacate, ácidos graxos insaturados, compostos bioativos.

\section{INTRODUCTION}

In 2011, world avocado production reached 4.4 million tons, increasing about $20 \%$ from 2007 to 2011 . Mexico is the largest avocado producer, accounting for $25 \%$ of the world production, followed by Chile with $8.5 \%$ (FAO, 2013). The increasing productivity has occurred due to advances in postharvest technologies, reduction in trade barriers,

\footnotetext{
'Programa de Pós-graduação em Ciência dos Alimentos, Centro de Ciências Químicas, Farmacêuticas e de Alimentos, Universidade Federal de Pelotas (UFPel), Pelotas, RS, Brasil.

IIPrograma de Pós-gradução em Ciência de Alimentos, Universidade Estadual de Maringá (UEM), Maringá, PR, Brasil.

IIICentro de Ciências Químicas, Farmacêuticas e de Alimentos, Universidade Federal de Pelotas (UFPel), Campus Universitário, CP 354, 96010-900, Pelotas, RS, Brasil. E-mail: carlaufpel@hotmail.com. *Corresponding author.
} 
strong health related claims, and increased incentives and cultivated areas in the producing countries (ALMEIDA \& SAMPAIO, 2013).

Brazil is the $9^{\text {th }}$ largest avocado producer, with 160,400 tons harvested in 10,750 hectares, in 2011. Avocado is the $17^{\text {th }}$ most produced fruit in the country, and São Paulo state is the largest producer (47.5\%), followed by Minas Gerais (19.0\%) and Paraná (11.2\%) (ALMEIDA \& SAMPAIO, 2013).

Avocado is an energetic fruit with high nutritional value and is considered a major tropical fruit, since it is rich in protein and contains fatsoluble vitamins lacking in other fruits, including Vitamins A and B, and median levels of vitamins $\mathrm{D}$ and E. It contains different oil levels in the pulp, thus it is widely used in pharmaceutical and cosmetic industries, and for obtaining commercial oils similar to olive oil, because of their similar fatty acid composition (BLEINROTH \& CASTRO, 1992). In addition, this fruit has been recognized for its health benefits, especially due to the compounds present in the lipid fraction, such as omega fatty acids, phytosterols, tocopherols, and squalene (SANTOS et al., 2014b).

This study aimed to present a literature review on the characteristics and applications of avocado (Persea americana), and its health benefits and potential uses of this poorly processed raw material in Brazil.

\section{The avocado crop}

The avocado tree originally from Mexico and Central America belongs to the Lauraceae family, genus Perseal and comprises two subgenres: Persea and Eriodaphne. The avocado grown for agricultural interests belong to two species of the genus Persea, being divided into three botanical varieties: Persea americana Miller var. Drymifolia (Mexican species); Persea americana Miller var. American (West Indian species); and Persea nubigena Miller var. Guatemalensis (Guatemalan species) (KOLLER, 1992).

The main climatic requirements of the avocado tree are related to the temperature and rain fall, and the varieties behave differently according to their race. The Antillean race (common), originating in the lowland regions of South America and Central America, has large fruits of piriform shape, with low oil content (less than $8 \%$ ), and is resistant to low temperatures, supporting up to $-2^{\circ} \mathrm{C}$. Varieties of the Guatemalan race, originating from the highlands of Central America, have fruit round in shape, with late maturation and higher oil content (8-20\%), and are more resistant to the cold than the Antillean race, which resist up to $-4^{\circ} \mathrm{C}$. In contrast, the Mexican races, originating in the highlands of Mexico and the Andes, are characterized for small fruits and high oil content (greater than $20 \%$ ), and are the most resistant to low temperatures (up to $-6^{\circ} \mathrm{C}$ ) (ALMEIDA \& SAMPAIO, 2013; HORTIBRASIL, 2013).

The avocado tree has a very high fruit yield, reaching a production of $138 \mathrm{~kg}$ at 7 years after planting. It is a perennial plant and can be grown on rough locations, not competing with the annuals adapted to flat lands (BLEINROTH \& CASTRO, 1992).

The fruits of variety Quintal are hybrids of Antillean and Guatemalan races, large sized (500800 grams), piriform, with green-smooth skin, yellow flesh, medium to large seeds, and relatively loose within the fruit. It is the most consumed variety in Brazil, and its lipid fraction comprises approximately $63 \%$ of omega-9 fatty acids (KOLLER, 1992). The avocado of the variety Hass is the most exported worldwide and has an average size of 180 to $300 \mathrm{~g}$ (BORGES \& MELO, 2011).

Avocado growth and development is intense, differing from other fruit species. After harvest, the fruit completes maturation, with major changes in metabolism and higher respiratory rate, and thus high production of ethylene, being highly perishable under environmental conditions leading to the production of high amounts of waste. In this sense, the avocado pulp processing can contribute to its best use, either as a food product or for oil extraction (KLUGE et al., 2002; SENAI, 2006; ROCHA, 2008).

\section{Fruit care and conservation}

In addition to its natural perishability, several factors such as mechanical damage, compression and cut, physiological, chemical and biochemical changes are responsible to changes in color, aroma, taste and texture of the fruit (SANCHES et al., 2008).

Although immediate external effects are not observed after impact, the pulp may be partially or completely dark when the fruit is ripe (BLEINROTH \& CASTRO, 1992; SANCHES et al., 2008). In the postharvest, refrigerated packaging $\left(4-7^{\circ} \mathrm{C}\right)$ is recommended to delay rot development. Wax application can also improve the appearance and increase the fruit's shelf life by reducing the transpiration rate and metabolic activity (DARVAS et al., 1990).

The cold storage to improve conservation can negatively affect lipids concentration and the longer the storage at low temperatures, the lower the fat content of the fruit (TREMOCOLDI, 2011). KLUGE et al. (2002) showed that the variety Quintal 
can be stored for 14 days at $7{ }^{\circ} \mathrm{C}$ and $85-90 \%$ relative humidity and then the commercialization can be at room temperature for 3 to 4 days.

Another inconvenience that depreciates the commercial value of the avocado is the enzymatic browning catalyzed by the enzyme polyphenol oxidase (PPO) and the degradative reactions of peroxidase (POD). The activity of these enzymes in various fruits and vegetables leads to considerable economic losses, in addition to reducing the nutritional and sensory quality. In some avocado varieties, the PPO activity increases after climacteric fruit ripening, with differences between varieties of the same species (LUÍZ et al., 2007). To control enzymatic browning reactions, acidulants such as citric acid may be added to preserve the fruit and to enable its use in food products (LUGO et al., 2006).

Whereas avocado is a climacteric fruit, the plant hormone ethylene can be controlled to extend its shelf-life using chemical compounds. For this purpose, the compound 1-methylcyclopropene, ethylene action inhibitor has been used. Its application can be in a gaseous state, being effective for 24 hours at $20^{\circ} \mathrm{C}$ and at concentrations ranging from $30 \mathrm{~nL} \mathrm{~L}^{-1}$ to $500 \mathrm{~nL} \mathrm{~L}^{-1}$ (PEREIRA et al., 2010).

Nutritional and physicochemical characteristics of avocado

Avocado is consumed in various forms in northern South America, Central America and Mexico, as puree salads, seasoned with salt, pepper, vinegar and other condiments, as well as being used in the preparation of other dishes (KOLLER, 1992). In Brazil, the ripe fruit is more appreciated, together with sugar, honey and liqueurs, and consumption is influenced mainly by its sensory and nutritional characteristics (LUÍZ et al., 2007).

The pulp content in several varieties is between 52.9 and $81.3 \%$, relative to fruit mass (TANGO et al., 2004). High lipids and low carbohydrate levels remain in avocado pulp after water removal, thus conferring a high dry matter content to the product. Therefore, it is considered one of the few cultured fruits presenting the lipid fraction as the major component (TREMOCOLDI, 2011 ), which can reach up to $25 \%$ of the fruit portion (HIERRO et al., 1992; ABREU et al., 2009).

The avocado pulp contains from 67 to $78 \%$ moisture, 13.5 to $24 \%$ lipids, 0.8 to $4.8 \%$ carbohydrate, 1.0 to $3.0 \%$ protein, 0.8 to $1.5 \%$ ash, 1.4 to $3.0 \%$ fiber, and energy density between 140 and $228 \mathrm{kcal}$ (SOARES \& ITO, 2000). Avocado has four (4) times more nutritional value than any other fruit except banana, containing proteins (1 to $3 \%$ ) and significant levels of fat-soluble vitamins (FRANCISCO \& BAPTISTELLA, 2005), folic acid, and appreciable amounts of calcium, potassium, magnesium, sodium, phosphorus, sulfur and silicon, and vitamins E, B1, B2, and D (DEMBITSKY et al., 2011).

The fruit stands out on potassium levels (339mg $100 \mathrm{~g}^{-1}$ ) when compared to other fruits, which regulates muscle activity and protects the body from cardiovascular diseases (CANCIAM et al., 2008). It also represents a source of glutathione, a powerful antioxidant that acts on potentially carcinogenic compounds (WANG et al., 2012).

\section{Bioactive compounds in avocados}

In addition to the important major compounds, avocado contains substantial amounts of bioactive compounds such as phytosterols, especially in the lipid fraction, and the main representative is the $\beta$-sitosterol (SALGADO et al, 2008b; SANTOS et al, 2014b). Diets rich in phytosterols can lead to the reduction of the total cholesterol and LDL cholesterol (LOTTENBERG, 2002). A 17\% decrease average in blood cholesterol levels was observed in a study in Mexico with 45 volunteers who consumed avocado once a day for one week (BORGES \& MELO, 2011).

Phytosterol is a substance of vegetable origin whose structure is very similar to cholesterol. Its mechanism of action in the body involves the inhibition of intestinal cholesterol absorption and decreased hepatic cholesterol synthesis. According to BRUFAU et al. (2008), it acts on total plasma cholesterol and LDL cholesterol without affecting HDL and blood triglycerides. The benefit of cholesterol reduction also comes from replacing saturated by unsaturated fats, which promote a decrease in total cholesterol and LDL and an increase in HDL levels (SALGADO et al., 2008a).

The $\beta$-sitosterol in avocados also has a special effect on immunity, contributing to the treatment of diseases such as cancer, HIV and infections. In relation to cancer, it works by suppressing carcinogenesis and in $\mathrm{HIV}$ by strengthening the immune system (BOUIC, 2002). This compound enhances lymphocytes proliferation and natural killer cell activity, which inactivates invading microorganisms (BOUIC et al., 1996). In addition, studies have shown that the $\beta$-sitosterol activity is an aid in weight loss by reducing compulsive eating binge and fat accumulation in the abdominal region (SENAI, 2006; MURTA, 2013).

The health effects of sterols and stanols have been the subject of several studies. Some authors 
have demonstrated a $25 \%$ reduction in the risk of coronary heart disease with the consumption of $2 g$ of such compounds per day, which are included in the formulations of margarines, spreads, and vegetable oils by esterification without affecting vitamins solubility (TURATTI, 2002).

The avocado oil variety Margarida contains a greater diversity of sterols, and $\beta$-sitosterol represents $71.8 \%$ of the total sterols, besides lower cholesterol levels $(0.3 \%)$, which can achieve up to $2.3 \%$ in other varieties (SALGADO et al., 2008b). SANTOS et al. (2014b) investigated the oil from Fortuna avocado extracted with petroleum ether and subjected to drying under forced air $\left(40^{\circ} \mathrm{C}\right)$, and found $87.6 \% \beta$-sitosterol, $12.41 \%$ campesterol, and $0.04 \%$ stigmasterol of the total phytosterols. Avocado also has a carotenoid named lutein that helps protect against prostate cancer and eye diseases such as cataracts and macular degeneration (JOHNSON, 2005).

\section{Avocado oil}

The avocado pulp contains high lipids content, which makes the pulp the portion of greatest interest. Lipids vary from 5 to $35 \%$, being formed mostly by unsaturated fatty acids (60-84\%) (BORGES $\&$ MELO, 2011). The avocado varieties with lower core and shell percentages are most interesting for oil extraction due to higher pulp yield, and the variety Quintal stands out (TANGO et al., 2004).

The high moisture content in fresh pulp is the main obstacle for obtaining avocado oil as it affects the extraction yield and production costs. Thus, the varieties most suitable for oil extraction, considering $18 \%$ lipids and low moisture levels in the pulp are: Hass, Fuerte and Glória, followed by the varieties Collinson, Anaheim, Itzamna, Wagner, Ouro Verde, Carlsbad and Mayapan (TANGO et al., 2004).

The traditional cold pressing method for vegetable oils was replaced by solvent extraction. Although some authors have reported a yield of $59 \%$ in oil extraction from fleshy pulp when using hexane, this value decreased to $12 \%$ when acetone was used as solvent (ABREU et al., 2009). However, the hexane residue in the extracted oil and cake may pose risks.

SANTOS et al. (2013) evaluated the extraction yield of Fortuna avocados oil as a function of the drying process (freeze-drying or air flow: 40 to $70^{\circ} \mathrm{C}$ ) and extraction method (pressing and solvent) of a pulp containing 5 to $6.5 \%$ moisture. The authors reported oil contents between 25 and $33 \%$ by cold pressing and between 45 and $57 \%$ by solvent extraction, while the freeze-drying method showed higher oil yield than the oven drying under forced air. The enzyme-assisted aqueous extraction has emerged as an alternative and environmentally friendly extraction process (ABREU et al., 2009).

The small avocado oil volume currently produced by some countries is used in its raw form by the pharmaceutical and cosmetics industries, once its unsaponifiable fraction is responsible for regenerative properties of the epidermis. Avocado oil is easily absorbed by the skin, with high absorption power of perfumes, which is of great value to the cosmetics industry. In addition, it easily forms an emulsion, ideal for the manufacture of fine soaps (TANGO et al., 2004).

In comparison to other vegetable oils, avocado oil is characterized by having high levels of monounsaturated fatty acids (oleic and palmitoleic acids), low polyunsaturated fatty acids (linoleic acid), and relatively high levels of saturated fatty acid (palmitic and stearic acids). This fatty acid composition is influenced by the cultivars, maturity stage, anatomical region of the fruit, and geographic location for plant growth (TANGO et al., 2004).

ROCHA (2008) has reported that avocado oil from the varieties Wagner, Fortuna, Hass and Fuerte had higher levels of monounsaturated fatty acid (MFA) ranging from 59 to $72 \%$ of total fatty acids, followed by saturated fatty acids (SFA), from 17 to $23 \%$, and polyunsaturated fatty acids (PUFA) to a lesser extent with levels ranging between 10 and 14\%.

SANTOS et al. (2014a) determined the fatty acids profile of Fortuna avocado, evaluating the effect of the pulp drying process (freeze-drying or air circulation: 40 and $70^{\circ} \mathrm{C}$ ) and oil extraction method (solvent or pressing). The authors reported that oleic fatty acid represented more than half of the total fatty acids of this raw material, together with substantial amounts of unsaturated linoleic and palmitoleic acids. They also verified that the dehydration of the pulp can affect the fatty acid profile since the oil extracted from the lyophilized pulp contained higher levels of unsaturated fatty acids. With respect to the extraction method, no significant effects were observed.

Avocado oils from the varieties Northrop, Duke, Wagner, Quintal, and Fuerte are characterized by having more than $63 \%$ oleic acid, while the oils from the varieties Rincon, Barker, Waldin, Prince and Panchoy showed less than $50 \%$ of this fatty acid. Palmitic acid content ranged between 15.38 and $32.37 \%$ in oils from different varieties. Therefore, the avocado variety affects the levels of palmitic acid and oleic acid, once varieties with high oleic acid levels had low palmitic acid levels and vice versa (BLEINROTH \& CASTRO, 1992). In addition to 
its fatty acid composition, these oils contain other bioactive minor components such as tocopherols, squalene, $\beta$-sitosterol, campesterol, and cycloartenol acetate, with positive effects on health (DEMBITSKY et al., 2011; SANTOS et al., 2014b).

Besides the possibility of using pure avocado oil as a substitute for olive oil, the combination of olive oil and avocado oil to replace olive oil mixtures (mainly using soybean oil) usually offered by the internal market is a promising alternative to reduce costs of Brazilian olive oil imports (SALGADO et al., 2008b). Avocado oil for salad dressings should be submitted to winterization to eliminate the saturated triglycerides, which can cloud the oil stored at low temperatures (SALGADO et al., 2008b).

Although the lipid extraction process generates large accumulation of pulp residues in the processing industries, the high fiber content of this by-product allows its use for preparation of flour to be used in bakery products like cookies, breads, and pasta thereby increasing the supply of fiber-rich products (CHAVES et al., 2013).

Applications and forms of preservation of avocado pulp

The processed products of avocado pulp include the paste, puree, and guacamole. Guacamole is a fruit pulp seasoned with salt, onion, lemon, pepper and tomato, being produced not only in an artisanal way but also marketed by some US companies (DAIUTO et al., 2011).

The sensory quality of guacamole of Hass variety made without chemical additives and stored under refrigeration was evaluated according to the type of packaging used. A greater consumers' acceptance was observed for the product stored in container with gas barrier when compared to that stored in polyethylene package (DAIUTO et al., 2011). Although these authors have also considered that the heat treatment may have been effective on the polyphenol oxidase inactivation, it can result in the development of bitterness and off-flavors in avocado, which changes the guacamole texture, negatively contributing to a mashed appearance.

CHAVES et al. (2013) studied avocado pulp Margarida variety dehydrated and defatted by cold pressing and avocado oil to partially replace wheat flour and butter, respectively, in whole grain crackers. The authors reported that the flour from avocado pulp, in general, showed characteristics similar to those of conventional flour and whole wheat flour. The biscuits had higher minerals and fiber levels, with good sensory acceptance.
Meat derivatives can also be supplemented with avocado pulp, since most of these processed foods contain relatively high levels of saturated fats in the formulation whose consumption is restricted by health issues. Thus, an alternative to reduce and enhance fatty acids balance is the incorporation of fats or vegetable oils in emulsified meat products (KAYAARDI \& GÖK, 2004; LUGO et al., 2006). The replacement of animal fats by vegetable oils in meat products has been studied with positive effects on the chemical, physical and sensory characteristics of the products, but with negative effects on water activity and texture (LUGO et al., 2006).

Products that contain high levels of vegetable oil, like avocado, are sensitive to oxidation, resulting in rancidity and hence production of undesirable flavors and loss of quality during storage. ELEZ-MARTINEZ et al. (2005) demonstrated the possibility to control oxidative rancidity in processed avocado puree with the use of $\alpha$-tocopherol and ascorbic acid.

Several preservation methods have been studied to obtain a stable avocado pulp, including pasteurization, drying, oil extraction, freezing, and freeze-drying (PALOU et al, 2000; SOLIVA et al., 2001; SOLIVA-FORTUNY et al, 2004). Use of microwave heating and copper chloride to preserve color of mashed avocado has been also investigated (GUZMÁN et al., 2002). Furthermore, chemical reducing agents, sequestrants, acids, nitrogen atmosphere and vacuum (SOLIVA et al., 2001) and high hydrostatic pressure treatment have been studied (JACOBO-VELÁZQUEZ \& HERNÁNDEZ-BRENES, 2012).

By-products

Avocado seed is underutilized and represents a large portion of the fruit, thus its use can be an alternative to reduce the production cost of edible oil. However, the main problem in the use of avocado seeds is the presence of phenolic compounds that exhibit toxicity. Studies have shown that the seeds can be used in feed for monogastric animals after extraction of these substances with ethanol (ICHIMARU et al., 1982). The extract may present antioxidant activity, once the phenolics levels in seeds vary from 2.3 to $5.7 \%$. In addition to the starch and fiber, there are other non-nitrogenous substances present in seeds, ranging from 5.1 to 13.2\% (SALGADO et al., 2008a).

Avocado leaves are a pharmaceutical ingredient widely used in extracts for therapeutic purposes, and also as teas in folk medicine (VENDRUSCOLO \& MENTZ, 2006), probably due to the diuretic properties (WRIGHT et al., 2007). 
Phytochemicals as orhamnetin, luteolin, rutin, quercetin, and apigenin have been isolated from avocado leaves, which can help prevent the progress of various diseases related to oxidative stress (OWOLABI et al., 2010).

\section{CONCLUSION}

Avocado can be an excellent alternative for industry, especially for pulp processing or oil extraction, considering its composition and the benefits of its compounds. Furthermore, the great diversity of plant species should be taken into consideration, since it provides the spread of cultivation and good availability of fruit, regardless of the time of year. This crop can be used for exportation and oil extraction, application in processed products, or as raw material in the pharmaceutical and cosmetic industries, generating high value added products. The pulp residue from oil extraction may also be used for manufacture of food products.

Several studies have demonstrated the health benefits of a balanced diet with avocado intake, especially in lowering cholesterol and preventing cardiovascular diseases. With increasing research on the nutritional characteristics and avocado benefits, it is expected an increase in production and exploitation of this raw material in Brazil, as observed in other countries.

\section{ACKNOWLEDGEMENTS}

The authors thank the research funds from MCTI/ Universal Conselho Nacional de Desenvolvimento Científico e Tecnólogico (CNPq) 14/2014 agreements $n^{\circ}$ 443288/2014-3 and avocado producer Mr. José Carlos Oliveira.

\section{REFERENCES}

ABREU, R.F.A.; PINTO, G.A. Extração de óleo da polpa de abacate assistida por enzimas em meio aquoso. In: SIMPÓSIO NACIONAL DE BIOPROCESSOS, 17., 2009, Natal, RN. Anais... Natal: Universidade Federal do Rio Grande do Norte, 2009. 6p. Available from: < http://ainfo.cnptia.embrapa.br/digital/bitstream/ CNPAT-2010/11482/1/AT09041.pdf > . Accessed: Jul. 11, 2013.

ALMEIDA, G.V.B.; SAMPAIO, A.C. O Abacate no mundo, no Brasil e na CEAGESP. Sociedade Brasileira de Fruticultura, 2013. Available from: $<$ http://www.todafruta.com.br/noticia/28119/O+A $\mathrm{BACATE}+\mathrm{NO}+\mathrm{MUNDO},+\mathrm{NO}+\mathrm{BRASIL}+\mathrm{E}+\mathrm{NA}+\mathrm{CEAGESP}>$. Accessed: Jul. 23, 2014.

BLEINROTH, E.W.; CASTRO, J.V. Matéria prima. In: ITAL. Abacate cultura, matéria-prima, processamento e aspectos econômicos. 2.ed. Série Frutas Tropicais. Campinas: ITAL, 1992. Cap.2, p.58-147.

BORGES, M.H.C.; MELO, B. A cultura do abacateiro. Available from: <http://www.fruticultura.iciag.ufu.br/abacate.html>. Accessed: Jun. 01, 2011.
BOUIC, P.J.D. Sterols and sterolins: new drugs for the immune system? Drug Discovery Today, v.7, n.14, p.775-778, 2002. Available from: <http:/www.sciencedirect.com/science/article/ pii/S1359644602023437>. Accessed: Dec. 22, 2015. doi: 10.1016/ S1359-6446(02)02343-7.

BOUIC, P.J.D. et al. Beta-sitosterol and beta-sitosterol glucoside stimulate human peripheral blood lymphocyte proliferation: Implications for their use as an immune modulatory vitamin combination. International Journal of Immunopharmacology, v.18, n.12, p.693-700, 1996. Available from: <http://www. sciencedirect.com/science/article/pii/S0192056197855518>. Accessed: Dec. 22, 2015. doi: 10.1016/S0192-0561(97)85551-8.

BRUFAU, G. et al. Phytosterols: physiologic and metabolic aspects related to cholesterol-lowering properties. Nutrition Research, v.28, p.217-225, 2008. Available from: <http://www.sciencedirect. com/science/article/pii/S0271531708000316>. Accessed: Dec. 22, 2015. doi: 10.1016/j.nutres.2008.02.003.

CANCIAM, C.A. et al. Elaboração e análise de iogurte sabor abacate, Ponta Grossa, PR, 2008. In: SEMANA DE TECNOlOGiA EM AlimentOS, 6., 2008, Ponta Grossa, PR. Anais... Ponta Grossa: Universidade Tecnológica Federal do Paraná, 2008. v.2, n.10, 3p.

CHAVES, M.A. et al. Preparation of whole cookie using avocado pulp flour and oil. Boletim do Centro de Pesquisa e Processamento de Alimentos, v.31, p.215-226, 2013. Available from: <http://dx.doi.org/10.5380/cep.v31i2.34844>. Accessed: Dec. 22, 2015. doi: 10.5380/cep.v31i2.34844.

DAIUTO, E.R. et al. Sensory analysis of cold-stored guacamole added with $\alpha$-tocopherol and ascorbic acid. Revista Ceres, v.58, n.2, p.140-148, 2011. Available from: <http://www.ceres.ufv.br/ ojs/index.php/ceres/article/view/3579/1471>. Accessed: Dec. 22, 2015. doi: 10.1590/S0034-737X2011000200002.

DARVAS, J.M. et al. Effect of treatment after picking on the incidence of post-harvest fruit diseases of avocado. Phytophylactica, v.22, n.1, p.93-96, 1990. Available from: <http://www.cabdirect.org/abstracts/19902301449.html>. Accessed: Dec. 22, 2015.

DEMBITSKY, V.M. et al. The multiple nutrition properties of some exotic fruits: Biological activity and active metabolites. Food Research International, v.44, p.1671-1701, 2011. Available from: <http://www.sciencedirect.com/science/article/pii/ S0963996911001608>. Accessed: Dec. 22, 2015. doi: 10.1016/j. foodres.2011.03.003.

ELEZ-MARTINEZ, P. et al. Natural antioxidants preserve the lipid oxidative stability of minimally processed avocado pure. Journal of Food Science, n.70, p.325-329, 2005. Available from: <http:// onlinelibrary.wiley.com/doi/10.1111/j.1365-2621.2005.tb09986.x/ abstract $>$. Accessed: Dec. 22, 2015. doi: 10.1111/j.13652621.2005.tb09986.x.

FAO (ORGANIZAÇÃO DAS UNIDAS PARA ALIMENTAÇÃO E AGRICULTURA). Available from: <http://www.fao.org>. Accessed: Jul. 16, 2013.

FRANCISCO, V.L.F.S.; BAPTISTELLA, C.S.L. Avocado cultivation in the state of São Paulo, Brazil. Revista Informações Econômicas, v.35, n.5, p.27-41, 2005. Available from: <http://www.almanaquedocampo.com.br/imagens/ 
files/A $\% 20 \mathrm{Cu}$ tura $\% 20 \mathrm{do} \% 20 \mathrm{Abacate} \% 20$ tec 3-0505. pdf $>$. Accessed: Dec. 22, 2015.

GUZMÁN, G.R. et al. Effect of zinc and copper chloride on the color of avocado puree heated with microwaves. Innovative Food Science and Emerging Technologies, v.3, n.1, p.47-53, 2002. Available from: <http://www.sciencedirect.com/science/article/ pii/S1466856401000534>. Accessed: Dec. 22, 2015. doi: 10.1016/ S1466-8564(01)00053-4.

HIERRO, M.T.G. et al. Determination of the triglyceride composition of avocado oil by high-performance liquid chromatography using a light-scattering detector. Journal of Chromatography, v.607, p.329-338, 1992. Available from: <http:// www.sciencedirect.com/science/article/pii/002196739287092M>. Accessed: Dec. 22, 2015. doi: 10.1016/0021-9673(92)87092-M.

HORTIBRASIL(INSTITUTO BRASILEIRO DE QUALIDADE EM HORTICULTURA). O Abacateiro e suas Variedades, 2013. Available from: <http://www.hortibrasil.org.br/jnw/ index.php?option $=$ com_content $\&$ vie $w=$ article $\&$ id $=1107: 0$ abacateiro-e-suas-variedades\&catid $=50$ :comercializacao\&Item id=82>. Accessed: Mar. 23, 2015.

ICHIMARU, D.L. et al. Estudo dos fatores antinutricionais do caroço de abacate (Persea americana Mill. cv. 'Wagner'). Coletânea do ITAL, v.12, p.67-83, 1982.

JACOBO-VELÁZQUEZ, D.A.; HERNÁNDEZ-BRENES, C. Stability of avocado paste carotenoids as affected by high hydrostatic pressure processing and storage. Innovative Food Science \& Emerging Technologies, v.16, p.121-128, 2012. Available from: $<$ http://www.sciencedirect.com/science/article/pii/ S1466856412000586> . Accessed: Dec. 22, 2015. doi: 10.1016/j. ifset.2012.05.001.

JOHNSON, E.J. Carotenoid actions and their relation to health and disease. Molecular Aspects of Medicine, v.26, n.6, p.459-516, 2005. Available from: <http://www.sciencedirect.com/science/ article/pii/S009829970500066X > Accessed: Dec. 22, 2015. doi: 10.1016/j.mam.2005.10.001

KAYAARDI, S.; GÖK, V. Effect of replacing beef fat with olive oil on quality characteristics of Turkish soudjouk (sucuk). Meat Science, v.66, n.1, p.249-257, 2004. Available from: <http:// www.sciencedirect.com/science/article/pii/S0309174003000986>. Accessed: Dec. 22, 2015. doi: 10.1016/S0309-1740(03)00098-6.

KLUGE, R.A. et al. Avocado ripening inhibition by 1-methylciclopropene. Revista de Pesquisa Agropecuária Brasileira, v.37, n.7, p.895-901, 2002. Available from: <http:// dx.doi.org/10.1590/S0100-204X2002000700001>. Accessed Dec. 22, 2015. doi: 10.1590/S0100-204X2002000700001.

KOLLER, O.C. Abacaticultura. Porto Alegre: UFRGS, 1992. 138p.

LOTTENBERG, A.M.P. et al. Plant sterol ester efficiency on the plasma lipid reduction in moderate hipercholesterolemic subjects. Arquivos Brasileiros de Cardiologia, v.79, n.2, p.139142, 2002. Available from: <http://dx.doi.org/10.1590/S0066782X2002001100005>. Accessed: Dec. 22, 2015. doi: 10.1590 S0066-782X2002001100005.

LUGO, U.R. et al. Substitución de lardo por grasa vegetal en salchichas: incorporación de pasta de aguacate. Efecto de la inhibición del oscurecimiento enzimático sobre el color. Revista de Ciência e Tecnologia de Alimentos, v.26, n.2, p.441-445, 2006. Available from: <http://dx.doi.org/10.1590/S010120612006000200030>. Accessed: Dec. 22, 2015. doi: 10.1590/ S0101-20612006000200030.

LUÍZ, R.C. et al. Kinetic of inactivation of polyphenoloxidase and peroxidase of avocado (Persea americana Mill.). Revista de Ciência e Agrotecnologia, v.31, n.6, p.1766-1777, 2007. Available from: <http://dx.doi.org/10.1590/S141370542007000600025>. Accessed: Dec. 22, 2015. doi: 10.1590/ S1413-70542007000600025.

MURTA, B. Óleo de abacate e seus benefícios. Revista Exame. Available from: <http://exame.abril.com.br/estilo-de-vida/saude/ noticias/oleo-de-abacate-e-seus-beneficios-veja-receitas?page $=1>$. Accessed: Jun. 13, 2013.

OWOLABI, M. A. et al. Bioactivity of the phytoconstituents of the leaves of Persea americana. Journal of Medicinal Plants Research, v.4, n.12, p.1130-1135, 2010. Available from: $<\mathrm{http}$ ://www.academicjournals.org/article/article1380715374 Owolabi\%20\%20et\%20al.pdf $>$. Accessed: Dec. 22, 2015. doi: 10.5897/JMPR09.429.

PALOU E. et al. High pressure-processed guacamole. Innovative Food Science and Emerging Technologies, v.1, p.69-75, 2000. Available from: $<$ http://www.sciencedirect.com/science/article/pii/ S1466856499000028>. Accessed: Dec. 22, 2015. doi: 10.1016/ S1466-8564(99)00002-8.

PEREIRA, M.E.C. et al. Amadurecimento e aceitação sensorial de abacate tratado com solução aquosa 1-MCP. In: CONGRESSO BRASILEIRO DE FRUTICULTURA, 21., 2010, Natal, RN. Anais... Natal: Sociedade Brasileira de Fruticultura, 2010. Available from: <http://www.alice.cnptia.embrapa.br/handle/ doc/874249>. Accessed: Jun. 13, 2013.

ROCHA, T.E.S. Composição de ácidos graxos e de fitoesteróis em frutos de quatro variedades de abacate (Persea Americana Mill). 2008. 85f. Dissertação (Mestrado em Nutrição Humana) Programa de Pós-graduação em Nutrição Humana, Universidade de Brasília, DF.

SALGADO, J.M. etal.Effect of the hass avocado (Persea americana Mill) on hipercolesterolemic rats. Revista Ciência Tecnologia de Alimentos, v.28, n.4, p.922-928, 2008a. Available from: <http:// dx.doi.org/10.1590/S0101-20612008000400025>. Accessed: Dec. 22, 2015. doi: 10.1590/S0101-20612008000400025.

SALGADO, J.M. et al. The avocado oil (Persea americana Mill) as a raw material for the food industry. Revista Ciência e Tecnologia de Alimentos, v.28, p.20-26, 2008b. Available from: <http:// dx.doi.org/10.1590/S0101-20612008000500004>. Accessed: Dec. 22, 2015. doi: 10.1590/S0101-20612008000500004.

SANCHES, J. et al. Application of mechanical damages in avocados and their effects to the quality of the fruits. Revista de Engenharia Agrícola, v.28, n.1, p.164-175, 2008. Available from: <http:// dx.doi.org/10.1590/S0100-69162008000100017>. Accessed: Dec. 22, 2015. doi: 10.1590/S0100-69162008000100017.

SANTOS, M.A.Z. et al. Efeito dos processos de secagem da polpa e extração do óleo de abacate no perfil de ácidos graxos. Revista Magistra, v.26, n. especial, p.149-153, 2014a. Available from: <https://www.ufrb.edu.br/magistra/2000-atual/volume-26ano-2014/1036->. Accessed: Dec. 23, 2015. 
SANTOS, M.A.Z. et al. Influence of preparing process of pulp and extration method in the oil yield of fortuna avocado. Higiene Alimentar, v.27, p.3776-3779, 2013.

SANTOS, M.A.Z. et al. Profile of bioactive compounds in avocado pulp oil: influence of dehydration temperature and extraction method. Journal of the American Oil Chemical Society, v.91, p.19-27, 2014b. Available from: <http://link.springer.com/ article/10.1007/s11746-013-2289-x>. Accessed: Dec. 22, 2015. doi: $10.1007 / \mathrm{s} 11746-013-2289-\mathrm{x}$.

SENAI (SERVIÇO BRASILEIRO DE RESPOSTAS TÉCNICAS). Óleo de abacate, 2006. Available from: <http://www.sbrt.ibict. br>. Accessed: May 14, 2011.

SOARES, H.F.; ITO, M.K. The monounsaturated fatty acid from avocado in the control of dyslipidemia. Revista Ciências Médicas, v.9, n.2, p.47-51, 2000. Available from: <http://periodicos. puc-campinas.edu.br/seer/index.php/cienciasmedicas/article/ viewFile/1330/1304>. Accessed: Dec. 23, 2015.

SOLIVA, R.C. et al. Evaluation of browning effect on avocado purée preserved by combined methods. Innovative Food Science \& Emerging Technologies, v.1, n.4, p.261-268, 2001. Available from: <http://www.sciencedirect.com/science/article/ pii/S1466856400000333>. Accessed: Dec. 22, 2015. doi: 10.1016/ S1466-8564(00)00033-3.

SOLIVA-FORTUNY, R.C. et al. Effect of combined methods of preservation on the naturally occurring microflora of avocado purée. Food Control, v.15, p.11-17, 2004. Available from: <http:// www.sciencedirect.com/science/article/pii/S0956713502001512>. Accessed: Dec. 22, 2015. doi: 10.1016/S0956-7135(02)00151-2.
TANGO, J.S. et al. Physical and chemical characterization of avocado fruits aiming its potencial for oil extraction. Revista Brasileira de Fruticultura, v.26, n.1, p.17-23, 2004. Available from: <http://www.scielo.br/pdf/rbf/v26n1/a07v26n1>. Accessed: Dec. 22, 2015. doi: 10.1590/s0100-29452004000100007.

TREMOCOLDI, M.A. Atividade antioxidante, compostos fenólicos totais e cor em abacate 'Hass' submetido a diferentes tratamentos físicos. 2011. 115f. Dissertação (Mestrado em Ciências Agronômicas) - Programa de Pós-graduação Ciências Agronômicas, Universidade Estadual Paulista Júlio de Mesquita Filho, SP.

TURATTI, J.M. Lipídeos: aspectos funcionais e novas tendências. Campinas: ITAL, 2002. 69p.

VENDRUSCOLO, G.S.; MENTZ, L.A. Ethnobotanical survey of the medicinal plants used by the community of Ponta Grossa neighborhood, Porto Alegre, Rio Grande do Sul, Brazil. Iheringia: Série Botânica, v.61, n.1-2, p.83-103, 2006. Available from: $<$ http:// dx.doi.org/10.1590/S1516-05722012000200010>. Accessed: Dec. 23, 2015. doi: 10.1590/S1516-05722012000200010.

WANG, M. et al. Effect of harvest date on the nutritional quality and antioxidant capacity in 'Hass' avocado during storage. Food Chemistry, v.135, p.694-698, 2012. Available from: <http:// www.sciencedirect.com/science/article/pii/S0308814612008461>. Accessed: Dec. 22, 2015. doi: 10.1016/j.foodchem.2012.05.022.

WRIGHT, C.I. et al. Herbal medicines as diuretics: A review of the scientific evidence. Journal of Ethnopharmacology, v.114, p.131, 2007. Available from: <http://www.sciencedirect.com/science/ article/pii/S0378874107003662>. Accessed: Dec. 22, 2015. doi: 10.1016/j.jep.2007.07.023. 